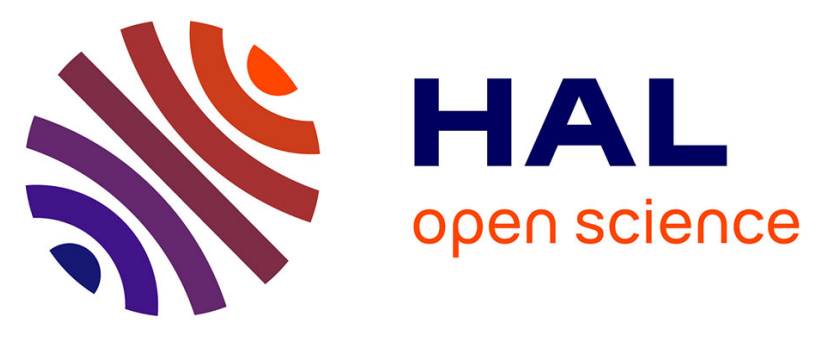

\title{
The Radio and Plasma Waves (RPW) Instrument on Solar Orbiter : Capabilities, Performance and First results.
}

\author{
Milan Maksimovic, Jan Souček, Stuart D. Bale, Xavier Bonnin, Thomas
} Chust, Yuri Khotyaintsev, Matthieu Kretzschmar, Dirk Plettemeier, Manfred Steller, Štěpán Štverák

\section{To cite this version:}

Milan Maksimovic, Jan Souček, Stuart D. Bale, Xavier Bonnin, Thomas Chust, et al.. The Radio and Plasma Waves (RPW) Instrument on Solar Orbiter : Capabilities, Performance and First results.. 22nd EGU General Assembly, 2020, Online, France. 10.5194/egusphere-egu2020-5800 . insu-03560753

\section{HAL Id: insu-03560753 \\ https://hal-insu.archives-ouvertes.fr/insu-03560753}

Submitted on 8 Feb 2022

HAL is a multi-disciplinary open access archive for the deposit and dissemination of scientific research documents, whether they are published or not. The documents may come from teaching and research institutions in France or abroad, or from public or private research centers.
L'archive ouverte pluridisciplinaire HAL, est destinée au dépôt et à la diffusion de documents scientifiques de niveau recherche, publiés ou non, émanant des établissements d'enseignement et de recherche français ou étrangers, des laboratoires publics ou privés.

\section{(c)(1)}

Distributed under a Creative Commons Attribution| 4.0 International License 
EGU2020-5800

https://doi.org/10.5194/egusphere-egu2020-5800

EGU General Assembly 2020

(c) Author(s) 2022. This work is distributed under

the Creative Commons Attribution 4.0 License.

\title{
The Radio and Plasma Waves (RPW) Instrument on Solar Orbiter : Capabilities, Performance and First results.
}

\author{
Milan Maksimovic ${ }^{1}$, Jan Souček ${ }^{2}$, Stuart D. Bale ${ }^{3,4}$, Xavier Bonnin ${ }^{1}$, Thomas Chust ${ }^{5}$, Yuri \\ Khotyaintsev ${ }^{6}$, Matthieu Kretzschmar ${ }^{7}$, Dirk Plettemeier ${ }^{8}$, Manfred Steller ${ }^{9}$, and Štěpán Štverák ${ }^{10}$ \\ ${ }^{1}$ LESIA, Observatoire de Paris, Université PSL, CNRS, Sorbonne Université, Univ. Paris Diderot, Sorbonne Paris Cité, 5 place \\ Jules Janssen, 92195 Meudon, France (milan.maksimovic@obspm.fr) \\ ${ }^{2}$ Institute of Atmospheric Physics, Czech Academy of Sciences, Prague CZ-14131, Czech Republic \\ ${ }^{3}$ Space Sciences Laboratory, University of California, Berkeley, CA, USA \\ ${ }^{4}$ Physics Department, University of California, Berkeley, CA, USA \\ ${ }^{5}$ LPP, CNRS, Ecole Polytechnique, Sorbonne Université, Observatoire de Paris, Université Paris-Saclay, PSL Research \\ University, Palaiseau, Paris, France \\ ${ }^{6}$ Swedish Institute of Space Physics (IRF), Uppsala, Sweden \\ ${ }^{7}$ LPC2E, CNRS, 3A avenue de la Recherche Scientifique, Orléans, France ; 7. Université d'Orléans, Orléans, France \\ ${ }^{8}$ Technische Universität Dresden, Würzburger Str. 35, D-01187 Dresden, Germany \\ ${ }^{9}$ Research Institute, Austrian Academy of Sciences, Graz, Austria \\ ${ }^{10}$ Astronomical Institute, Czech Academy of Sciences, CZ-14100 Prague, Czech Republic
}

We will review the instrumental capabilities of the Radio and Plasma Waves (RPW) Instrument on Solar Orbiter which at the time of writing this abstract is planned for a launch on February $5^{\text {th }}$ 2020. This instrument is designed to measure in-situ magnetic and electric fields and waves from 'DC' to a few hundreds of $\mathrm{kHz}$. RPW will also observe solar radio emissions up to $16 \mathrm{MHz}$. The RPW instrument is of primary importance to the Solar Orbiter mission and science requirements, since it is essential to answer three of the four mission overarching science objectives. In addition, RPW will exchange on-board data with the other in-situ instruments, in order to process algorithms for interplanetary shocks and type III Langmuir waves detections. If everything goes well after the launch, we will hopefully be able to present the first RPW data and results gathered during the commissioning. 